\title{
O DIREITO À INFORMAÇÃO AMBIENTAL SUSTENTÁVEL NO CONTEXTO BRASILEIRO: A DECLARAÇÃO SOBRE O PRINCÍPIO 10 NA AMÉRICA LATINA E NO CARIBE E O PROJETO DE LEI No $.4148 / 2008$
}

\author{
THE RIGHT TO ENVIRONMENTAL INFORMATION ON SUSTAINABLE \\ BRAZILIAN CONTEXT : THE DECLARATION OF PRINCIPLE 10 IN LATIN \\ AMERICA AND THE CARIBBEAN AND THE BILL Nº 4148/2008
}

\author{
1Jerônimo Siqueira Tybusch \\ ${ }^{2}$ Evilhane Jum Martins
}

\section{RESUMO}

As discrepâncias existentes entre o Projeto de Lei nº4148\&\#8725;2008 e o Princípio 10, que dispõe acerca do compromisso dos Estados em garantir o acesso à informação ambiental, geram a necessidade de reflexões sobre os reais paradigmas brasileiros frente à tal compromisso, assim como a sustentabilidade informacional enquanto pressuposto para a concretização de direitos. Assim, objetiva-se de modo geral, analisar as disposições pertinentes ao Princípio 10, as perspectivas da Declaração sobre o Princípio 10 na América Latina e no Caribe e averiguar os fundamentos do Projeto de Lei ${ }^{\circ} 4148 \& \# 8725 ; 2008$, sob a perspectiva da sustentabilidade informacional. Após pretende-se especificadamente, delinear as contraposições entre os objetivos internacionais e o referido projeto de lei. Busca-se responder a indagação: Os fundamentos que levaram o Projeto de Lei $\mathrm{n}^{\circ}$. 4148\&\#8725;2008 à apreciação do Congresso Nacional e sua aprovação na Câmara dos Deputados, podem ser considerados como contraposição aos compromissos internacionais assumidos pelo Brasil, no que diz respeito à informação ambiental sustentável, consubstanciando-se em um retrocesso normativo? A metodologia empregada possui como Teoria de Base e Abordagem a perspectiva sistêmico-complexa. Os procedimentos são pesquisa bibliográfica e documental. A técnica empregada é construção de fichamentos e resumos. Conclusivamente, vislumbra-se que o Brasil vem adotando paradigmas contraditórios quanto ao direito à informação ambiental, os quais necessitam ser melhor delineados, sob pena dessas contrariedades consubstanciarem-se em retrocesso normativo.

Palavras-chave: Projeto de lei nº $4148 \& \# 8725,2008$, Princípio 10, Informação ambiental sustentável

\footnotetext{
${ }^{1}$ Doutor em Interdisciplinar em Ciências Humanas pela Universidade Federal de Santa Catarina - UFSC, Santa Catarina (Brasil). Professor de Direito pela Universidade Federal de Santa Maria - UFSM, Rio Grande do Sul (Brasil). E-mail: jeronimotybusch@ufsm.br

${ }^{2}$ Mestranda em Direito pela Universidade Federal de Santa Catarina - UFSC, Santa Catarina (Brasil).

E-mail: evilhane_martins@ hotmail.com
} 


\begin{abstract}
Discrepancies between the Bill $\mathrm{n}^{\circ} 4148$ / 2008 and Principle 10, which has about the commitment of States to ensure access to environmental information, generate the need for reflection on the actual Brazilian paradigms front of such a commitment, as well as sustainability Informational as a prerequisite to the realization of rights. Thus, the objective is to generally examine the relevant provisions to Principle 10, the prospects of the Declaration on Principle 10 in Latin America and the Caribbean and investigate the fundamentals of Bill No. 4148/2008, from the perspective of informational sustainability . After it is intended specifically delineate the contrasts between international goals and the said bill. It seeks to answer the question: The reasons which led the Law No. Project. 4148/2008 to the National Congress and its approval in the Chamber of Deputies, can be considered as opposed to the international commitments made by Brazil, with regard to sustainable environmental information, consolidating in a legal setback? The methodology has as basis of theory and approach to systemic-complex perspective. Procedures are bibliographical and documentary research. The technique is building fichamentos and summaries. Conclusively, one sees that Brazil has adopted contradictory paradigms for the right to environmental information, which need to be better delineated, otherwise these setbacks consubstanciarem in legal setback.
\end{abstract}

Keywords: Bill no. 4148/2008, Principle 10, Environmental information sustainable 


\section{INTRODUÇÃO}

A revolução informacional iniciada no século XX, trás consigo novas possibilidades de governança e de relacionamento humano, além de alavancar o processo de globalização, consubstanciando-se como a base estrutural do processo de interligação global e um dos principais paradigmas que caracterizam a contemporaneidade. É nesse sentido que a informação ambiental configura-se como o ponto de partida para a congregação de esforços a fim de conter a degradação ambiental, assim como disseminar práticas responsáveis no que concerne a utilização dos recursos naturais e promover o conhecimento a respeito da existência de práticas que acabam por devastar o meio ambiente e prejudicar a saúde humana: as quais tão somente a partir da difusão informacional podem ser freadas ou reprimidas.

Nessa perspectiva, é que o Princípio 10 - diretiva internacional proposta durante a Conferência da ONU sobre o Meio Ambiente e o Desenvolvimento, no Rio de Janeiro em 1992, a chamada ECO-92 - dispõe acerca do compromisso dos Estados em garantir aos seus cidadãos o acesso à informação, à justiça e à participação popular nas questões ambientais perfazendo desta forma a sustentabilidade informacional -, compromisso este que os países da América Latina e Caribe, inclusive o Brasil, envidam esforços para concretizar desde o advento da Declaração sobre o Princípio 10 na América Latina e no Caribe.

Sob ótica diversa, a emergência do consumo, a necessidade de se garantir a segurança alimentar, assim como os aspectos econômicos que permeiam a produção de monoculturas e incentivam a transgenia, mostram-se no contexto brasileiro atual como possíveis contraposições ao direito à informação ambiental. Tal afirmação decorre dos entraves pertinentes ao Projeto de Lei $\mathrm{n}^{\circ}$. 4148/2008, que tramita no Congresso Nacional pendente de aprovação pelo Senado Federal - o qual propõe modificações nas informações que devem ser disponibilizadas nos rótulos de alimentos que possuam natureza transgênica, apresentando contrariedades ao Decreto $n^{\circ} .46802003$ e a Portaria $n^{\circ}$. 2658/2003 do Ministério da Justiça.

Frente a tais contraposições, a presente pesquisa objetiva de modo geral, analisar as disposições pertinentes ao Princípio 10 e por consequência, as perspectivas insertas na Declaração sobre o Princípio 10 na América Latina e no Caribe e seus resultados, bem como averiguar os fundamentos que embasam o Projeto de Lei $n^{\circ}$. 4148/2008. Posteriormente, pretende-se de forma específica, delinear as possíveis contraposições entre a norma internacional e o Projeto de Lei que tramita no Congresso Nacional brasileiro, bem como verificar os fundamentos e pressupostos capazes de evocar o descompasso entre o 
compromissos assumidos pelo Brasil internacionalmente no que tange à informação ambiental sustentável e as ações praticadas no âmbito interno acerca da temática.

Nesse diapasão, a reflexão proposta sustenta-se na seguinte problemática: Os fundamentos que levaram o Projeto de Lei n ${ }^{\circ} .4148 / 2008$ à apreciação do Congresso Nacional e sua consequente aprovação na Câmara dos Deputados, podem ser considerados uma efetiva contraposição aos compromissos internacionais assumidos pelo Brasil - no que diz respeito à informação ambiental sustentável - e por consequência, consubstanciar-se em um possível retrocesso normativo?

Para responder a este questionamento a metodologia empregada obedece ao trinômio: Teoria de Base/Abordagem, Procedimento e Técnica. Como Teoria de Base e Abordagem optou-se pela perspectiva sistêmica utilizando-se autores com visão multidisciplinar e conectando ares do saber como direito informacional, ecologia política e sociologia. Os procedimentos elegidos foram a pesquisa bibliográfica e documental (em meios físicos e digitais - sites e redes sociais). A técnica empregada foi a construção de fichamentos e resumos estendidos.

Dessa forma, a pesquisa que aqui se desenvolve está dividida em três capítulos sistematicamente interligados: primeiramente, aborda-se as atuais conjecturas do direito informacional e da sustentabilidade da informação, assim como a consagração do Princípio 10 na ordem mundial, sedimentando-se a relevância da informação ambiental sustentável. Em continuidade, no segundo capítulo averigua-se o transcurso das ações envidadas pela América Latina e o Caribe para a consagração do Princípio 10 através de um instrumento regional comum e sua relevância. Por conseguinte, verifica-se as contraposições existentes entre o processo de consagração dos fundamentos do Princípio 10 na América Latina e o Projeto de Lei $\mathrm{n}^{\circ}$. 41482008, assim como as possíveis motivações de caráter mercadológico que asseveram tais discrepâncias.

Diante do exposto, repensar os paradigmas que regem a sustentabilidade informacional ambiental no Brasil - os quais indiscutivelmente precisam ser melhor delineados - é tarefa irremediável, sob pena de vislumbrar-se retrocessos normativos, informacionais e socioambientais de caráter internacional. 


\section{DIREITO INFORMACIONAL SOB A ÓTICA DO PRINCÍPIO 10: A construção da sustentabilidade informacional}

A interrelação existente entre informação e poder em suas diversas acepções, por si só pode ser considerada capaz de demonstrar a supremacia do direito à informação enquanto condicionante para a concretização de outros direitos, por vezes fundamentais à vida humana.

No que tange a sustentabilidade informacional, tem-se que imprescindível se torna a sua garantia por consistir em elemento crucial para o empoderamento dos cidadãos, tendo em vista sua capacidade de garantir decisões democráticas no plano sociopolítico no momento em que a participação popular por meio do acesso à informação sustentável constitui-se como pressuposto para a efetiva prática democrática.

Tal constatação se vislumbra no plano prático por intermédio de dois paradigmas: o primeiro identifica-se pela necessidade de se ter informação sustentável prévia enquanto pressuposto para a concretização de direitos; o segundo corresponde a possibilidade de propagar ou não, informações que irão direcionar a conduta dos indivíduos a fim de que esses possam ou não, efetivar direitos ou ainda constituir direitos oriundos de práticas sociais coletivas.

Sob esse aspecto a dicotomia entre informação e poder na era contemporânea passa a designar desde questões humanas comportamentais, alcançando a dimensão de determinar princípios, orientações e regras que irão direcionar as ações sociopolíticas de uma nação em meio a esfera informacional mundial. Nesse diapasão, a partir de uma análise global observase de pronto que para se averiguar as questões sociais, políticas e ambientais que permeiam a proveniência do Princípio 10 - enquanto disposição internacional cuja origem advém do reconhecimento por diversos Estados, da necessidade de se garantir a informação ambiental assim como as intempéries que dificultam ou impedem sua aplicação na íntegra, configura-se como pressuposto verificar as condições que propiciaram a difusão e a sobreposição do direito à informação na era contemporânea.

\subsection{A SOCIEDADE CONTEMPORÂNEA E O DIREITO À INFORMAÇÃO SUSTENTÁVEL}

O pensamento de que a era contemporânea possui como marco do progresso mundial convergente a difusão e propagação da informação, não ganha contraposições doutrinárias ${ }^{1}$.

\footnotetext{
${ }^{1}$ Maria Eduarda Gonçalves, ao discorrer acerca do assunto afirma que: Nas últimas décadas, várias correntes do pensamento social têm convergido na noção de que as sociedades entraram numa fase nova do seu desenvolvimento. As teorias da sociedade pós-industrial e da informação ( Bell, 1976; Masuda, 1981; Pool,
} 
Sabe-se que o fenômeno da globalização ${ }^{2}$ a partir do século XX foi responsável pela nova dimensão valorativa decorrente da sociedade contemporânea: deixa de prevalecer - enquanto alvo de investimentos e pressuposto para o desenvolvimento mundial - questões relacionadas à industrialização e ao trabalho enquanto força motriz que impulsiona o capital, cedendo espaço para a valorização de recursos imateriais capazes de modificar as estruturas do sistema socioeconômico mundial, o qual passa a ancorar-se em questões relacionadas ao conhecimento tecnocientífico, às comunicações, à tecnologia, aos dados e à informação.

Sob esse aspecto, as transformações ocorridas na ordem pública e privada emergem para um novo modo de interrelação mundial, onde distâncias territoriais, culturais e sociais cedem espaço para aproximações decorrentes de uma nova estrutura socioeconômica mundial, capaz de identificar as necessidades e problemáticas inerentes a cada povo. Pierre Lévy, ao dissertar acerca de tal fenômeno preleciona:

\begin{abstract}
Os economistas que negam - e eles existem - a novidade e a importância da fase atual de globalização, aproximando-a da situação que prevalecia antes da Primeira Guerra Mundial, enganam-se completamente. É correto dizer que o movimento contemporâneo de interconexão econômica do planeta prolonga uma tendência de vários séculos, a qual conheceu uma fase temporária de recuo na primeira metade do século XX (as guerras mundiais, a emergência dos nacionalismos e a recessão dos anos 30). Mas o desenvolvimento das rodovias, do automóvel individual, da estrada de ferro, da aviação, do turismo, das mídias, das telecomunicações, em geral, e do ciberespaço em particular, assim como os avanços do sufrágio universal, a liberação dos costumes, a urbanização crescente e a expansão da ciência e da técnica, todas essas evoluções produziram uma humanidade infinitamente menor, mais densa, mais rápida, mais comerciante, mais consumista, mais comunicativa, mais produtiva, mais inteligente, mais consciente de si mesma e de seu planeta, se comparada àquela do fim do século XIX. Jamais estivemos tão perto uns dos outros. Nunca nos
\end{abstract}

1983; Lyon, 1995; Webster, 1996), do conhecimento (Drucker, 1993), pós-moderna (Lyotard, 1989), e, mais recentemente as teorias da sociedade de risco (Beck, 1992; Giddens, 1998) variam na identificação das forças da mudança. Mas todas elas, de uma forma ou de outra, têm posto em evidência que a sociedade contemporânea é marcada profundamente pelo progresso e utilização das ciências e das tecnologias, em particular das tecnologias da informação e da comunicação, pela substituição da informação ao capital e ao trabalho como recurso estratégico da economia e pela expansão dos riscos de base industrial e tecnológica. Ainda que se reconheça que este conjunto de fenômenos obedece a lógicas e dinâmicas distintas, aceita-se que confluem na sua natureza ou implicações transnacionais - o que conduz alguns autores a enquadrá-los num conceito abrangente de globalização ou "ordem global” (Waters, 1995: 2; Robertson, 1996; Held e McGrew, 1999:483; Santos, 2001; Webster, 2001) (2003 p. 27).

2 Para fins de maior compreensão do vocábulo "globalização" no contexto apresentado, importante referir a definição elaborada por Canclini: O processo que começamos a descrever como globalização pode ser resumido como a passagem das identidades modernas a outras que poderíamos chamar, embora o termo seja cada vez mais incomodo, de pós-modernas. As identidades modernas eram territoriais e quase sempre monolinguisticas. Consolidaram-se subordinando regiões e etnias dentro de um espaço mais ou menos arbitrariamente definido, chamado nação, opondo-o - sob a forma dada pela sua organização estatal - a outras nações. Ainda em zonas multilinguisticas, como é a região andina e a centro-americana, as políticas de homogeneização modernizadora esconderam a diversidade cultural sob o domínio do espanhol e a variedade de formas de produção e consumo dentro dos formatos nacionais.Por outro lado as identidades pós-modernas são transterritoriais e multilinguisticas. Estruturam-se menos pela lógica dos Estados do que pela dos mercados; em vez de se basearem nas comunicações orais e escritas que cobriam espaços personalizados e se efetuavam através de interações próximas, operam mediante a produção industrial de cultura, sua comunicação tecnológica e pólo consumo diferido e segmentado dos bens (CANCLINI, 1999, p. 59). 
misturamos tanto. Nunca houve tantos planetários. Jamais houve juventude mundial, música mundial, cultura mundial como há agora. $\mathrm{O}$ fim do século $\mathrm{XX}$ marca um limiar decisivo e irreversível do processo de unificação planetária da espécie.( 2001, p. 25-26).

Manuel Castells e Gustavo Cardoso, ao tratarem do advento da sociedade contemporânea e, por conseguinte da indispensabilidade da era informacional enquanto elemento propulsor do desenvolvimento mundial na escala tecnológica, afirmam que o globo é palco de um processo de transformação estrutural, transformação esta desencadeada pelas tecnologias da comunicação e informação. No entanto os autores revelam que esse novo paradigma tecnológico não é capaz de distanciar-se ou diferenciar-se da sociedade, ambos discorrem que nos tempos atuais a tecnologia é a sociedade: pois a sociedade é quem dá forma à tecnologia (2005, p. 17).

Logicamente a indispensabilidade das novas tecnologias para o advento da informação, é indiscutível. No entanto, observa-se que as tecnologias e novas formas de comunicação consistem em mecanismos para a difusão da informação, ou seja, a finalidade maior que reúne o arcabouço de mecanismos tecnológicos para sua aquisição ou sua propagação é a informação, a qual pode consubstanciar-se em diversas formas do saber, em material de consumo, ou ainda pode consistir na não-informação. Patrícia Peck ao tratar do direito à informação, dispõe:

\begin{abstract}
A sociedade digital já não é uma sociedade de bens: é uma sociedade de serviços, onde a posse da informação prevalece sobre a posse dos bens de produção. Esta característica faz com que a proteção do direito à informação seja um dos princípios basilares do Direito Digital, assim como a proteção de seu contradireito, ou seja, do direito à não-informação.

$\mathrm{O}$ direito à informação está desmembrado em três categorias de acordo com o sujeito de direito: a) direito de informar, que é um direito ativo; b) o direito de ser informado, que é um direito passivo; c) o direito de não receber informação, que é um direito ativo e passivo (2002, p.36).
\end{abstract}

Embora a autora trate da não-informação enquanto direito, torna-se relevante salientar que a não-informação pode consubstanciar-se como contraposição ao direito à informação, de modo que por objetivos econômicos ou políticos a informação, que não mais consiste tão somente em objeto de ordem pública, mantenha-se inacessível ou não publicizada $^{3}$.

\footnotetext{
${ }^{3}$ Visando exemplificar a possibilidade da não-informação como contraposição ao direito à informação, no presente caso em vista de questões econômicas, dentre outras várias situações que podem ser citadas, veja-se a presente descrição de Jean Lojkine: ... os tipos de cooperação atualmente dominantes entre laboratórios públicos e empresas privadas consagram, muito mais que uma "parceria" e uma livre circulação de uma informação cientifica que o serviço público destina ao conjunto da coletividade, o triunfo do monopólio privado, da concorrência entre empresas gigantescas, proprietárias de bancos de dados - esta parece ser a conclusão, em um recente dossiê sobre a "parceria" nas informações científicas, a que chega a revista norte-americana Science. Centrando-se, especialmente, na difusão de informações referentes às pesquisas em biotecnologia, os autores do
} 
Nessa ordem, a sustentabilidade informacional preconiza justamente o inverso: democratização de acesso, empoderamento dos cidadãos e participação popular e democrática na construção de ideais e na tomada de decisões sociopolíticas, revelam-se como efeitos da sustentabilidade informacional, os quais podem ser considerados como indispensáveis e irrefutáveis na sociedade contemporânea. Em contraposição no que tange a sustentabilidade da informação ambiental, Jerônimo Siqueira Tybusch preleciona:

\begin{abstract}
Nessa perspectiva, compreende-se que existe uma maior influência do saber e poder econômicos na comunicação ecológica. Ou seja, as práticas discursivas, no que respeita à questão ambiental, partem, na realidade, das políticas públicas, de orientações desenvolvimentistas, resultando em ações que operam a partir de uma lógica de custo/ benefício ou de um código valor/ não valor para, em um segundo momento, tentar adequá-las na perspectiva da sustentabilidade (2013, p. 225-226).
\end{abstract}

Nesse sentido, as informações ambientais de ordem genética, ou ainda aquelas pertinentes a diversidade de espécies as quais são amplamente utilizadas pela biotecnologia, bem como informações pertinentes a transgenia, possuem caráter estratégico no que concerne ao não fornecimento de informações ou então à difusão de informações previamente determinadas e articuladas - o que se contrapõe veementemente à informação sustentável -, atrelado ao desenvolvimento de ações prejudicais à biodiversidade ou que visam tão somente a obtenção de lucros. Assim, tratar-se-á então acerca do Princípio 10 enquanto garantidor do fornecimento da informação ambiental sustentável no âmbito internacional, vislumbrando-se as diretivas existentes para o enfrentamento de tal problemática.

\title{
1.2 O PRINCÍPIO 10 ENQUANTO PROPULSOR DA INFORMAÇÃO AMBIENTAL SUSTENTÁVEL
}

Antes de adentrar-se na questão que aqui se propõe, importante referir, de acordo com os argumentos exarados anteriormente, as várias dimensões que compõem o direito à informação, o que se pode observar com as palavras da doutrinadora Patricia Peck antes citada. A partir de então, cuidar-se-á do direito à informação no que se refere à dimensão pertinente ao acesso, tendo em vista as características da informação ambiental e da sustentabilidade da informação enquanto objeto de regulação pelo Princípio 10. Sendo assim, pertinente referir as razões de Fernando Antonio Urioste Braga ao dissertar sobre a relevância de tratar-se do direito à informação sob a perspectiva do acesso:

Ocurre que la visión que predomina en quienes se acercan a estos temas procura vincular la información al âmbito político o público en una sociedad democrática

dossiê constatam na América do Norte, um "declínio" das referências a uma "propriedade comum" das informações científicas e uma forte tendência a filtrar as informações difundidas, de modo a proteger os interesses dos parceiros privados e a promover o patenteamento do resultado das investigações (2002,p. 201). 
que se basa en el poder de la opinión pública. Insisten en la denominación de derecho a la información, porque se parte de la premisa, cierta de que la información es poder. Y según esto, el ocultamiento de esa información como instrumento de poder supone que se está retaceando a la opinión pública parcelas de información que son necesarias para tomar sus decisiones. Como consecuencia, el ocultamiento es parte de la manipulación política. Por eso se insistirá también en la ponderación de la información como poder, y se hace del acceso a la información el capítulo más importante, con lo cual se vincula la información con aquella de contenido político e se le también un fundamento en la sociedad democrática. Hay entonces en sus fundamentos un claro paralelismo con la libertad de expresión cuya dimensión social se vincula al régimen democrático (2008, p. 86).

Realizadas tais considerações, necessário que se faça uma breve retrospectiva acerca do surgimento do Princípio 10.

Buscando sedimentar os ideais exarados na Declaração da Conferência das Nações Unidas sobre o Meio Humano ${ }^{4}$, aprovada em Estocolmo em 16 de junho de 1972, e baseandose em seus fundamentos, a Declaração do Rio de Janeiro sobre Meio Ambiente e Desenvolvimento efetuada entre os dias 03 à 14 de junho de 1992 possuía enquanto objetivo maior promover a cooperação efetiva entre Estados no que pertine ao respeito aos interesses humanos, a proteção do sistema ambiental e ao alcance do desenvolvimento sustentável em âmbito mundial. Dessa forma, elaborou-se diversos princípios que a partir de então passariam a reger a atuação estatal a fim de se alcançar o objetivo geral antes referido.

Dentre tais princípios, o Princípio 10 inserto na Declaração do Rio sobre Meio Ambiente e Desenvolvimento, trata do acesso à informação ambiental em três acepções que podem ser identificadas como o acesso à informação propriamente dito, a participação pública e o acesso à justiça, delineados da seguinte forma:

\begin{abstract}
A melhor maneira de tratar questões ambientais é assegurar a participação, no nível apropriado, de todos os cidadãos interessados. No nível nacional, cada indivíduo deve ter acesso adequado a informações relativas ao meio ambiente de que disponham autoridades públicas, inclusive informações sobre materiais e atividades perigosas em suas comunidades, bem como a oportunidade de participar em processos de tomada de decisões. Os Estados devem facilitar e estimular a conscientização e a participação pública, colocando a informação à disposição de todos. Deve ser propiciado acesso efetivo a mecanismos judiciais e administrativos, inclusive no que diz respeito à compensação e reparação de danos (1992,p. 02) .
\end{abstract}

Com a ratificação da Declaração do Rio de 1992 na Assembleia Geral da Organização das Nações Unidas em 12 de agosto de 1992, verificar-se-ia a trajetória

\footnotetext{
${ }^{4}$ La Conferencia de Estocolmo es el comienzo del rodaje del tema ambiental, que sucesivamente será considerado cada vez con más intensidad y peores perspectivas en las décadas siguientes. En junio de 1972, la conferencia sobre "El medio ambiente humano" aborda estos problemas. Comienza por señalar y reconocer la fundamental tarea realizada por la ciência y la técnica, obra humana que há transformado el mundo natural para asegurar el bienestar de los pueblos y su desarollo econômico. Pero esta ciencia y esta técnica aplicada de modo errôneo o en forma imprudente - dice la declaración - "pueden"causar daños incalculables al ser humano y a su médio, por la contaminación del água, el aire y los seres vivos (BRAGA, 2008, p. 217).
} 
estrutural consistente na modificação de prioridades político administrativas, as quais deveriam ser perseguidas pelos Estados contratantes.

Obviamente, conforme observações efetuadas em fase anterior - pois desde a Conferência de Estocolmo já existia tal constatação - e durante a Conferência do Rio de 1992, os desafios para implantação dos princípios propostos assumiriam contornos distintos, a depender de questões regionais que poderiam favorecer ou prejudicar a aplicação no plano prático dos ideais que ali foram apresentados, e já neste primeiro momento poder-se-ia vislumbrar a influência de determinadas questões econômicas sobre a possibilidade de efetivação dos princípios adotados pela Declaração do Rio de 1992, e por consequência da informação ambiental sob o prisma tratado pelo Princípio 10.

\begin{abstract}
Sem dúvida, o sentimento geral com que a América Latina e o Caribe chegaram à Conferência do Rio de 1992, era muito diferente daquele de Estocolmo 20 anos antes. Desta vez, os países em desenvolvimento estavam muito mais satisfeitos com a chamada. Na verdade, neste, ao contrário de 1972, não será mais possível ler que a principal causa da deterioração do meio ambiente global foi a "explosão populacional" (que ocorre principalmente em países do Terceiro Mundo). Pelo contrário, havia agora uma percepção absoluta da crise ambiental como sendo de responsabilidade primeira de países altamente industrializados e desenvolvidos ou de Primeiro Mundo, que a tinha produzido e, portanto, deveriam assumir a responsabilidade sobre o problema, incluindo a desigualdade social mundial que provocaram com seu modelo de expansão e desenvolvimento. E neste sentido a grande desigualdade social e política que caracterizava o mundo contemporâneo era parte da crise ambiental global (SAAVEDRA, 2014, p. 199).
\end{abstract}

Assim, os desafios e ideais provenientes da Conferência do Rio de 1992 e, mais especificadamente da Declaração do Rio de Janeiro sobre Meio Ambiente e Desenvolvimento por intermédio do Principio 10 enquanto propulsor do acesso à informação ambiental, iriam conduzir-se de maneira distinta entre regiões do planeta marcadas pela (in)existência do embate desenvolvimentista.

No ano de 2012, A Conferência das Nações Unidas sobre Desenvolvimento Sustentável - Rio + 20, ratifica os ideais exarados na Declaração do Rio de $1992^{5}$. Sob essa

\footnotetext{
${ }^{5}$ Recalcamos que la participación amplia del público y el acceso a la información y los procedimientos judiciales y administrativos son esenciales para promover el desarrollo sostenible. El desarrollo sostenible requiere la implicación efectiva y la participación activa de las autoridades legislativas y judiciales regionales, nacionales y subnacionales, así como de todos los grupos principales: mujeres, niños y jóvenes, pueblos indígenas, organizaciones no gubernamentales, autoridades locales, trabajadores y sindicatos, empresas e industria, comunidad científica y tecnológica y agricultores, y demás interesados, como las comunidades locales, los grupos de voluntarios y las fundaciones, los migrantes, las familias, las personas de edad y las personas con discapacidad. A este respecto, convenimos en colaborar más estrechamente con los grupos principales y demás interesados y los alentamos a que participen activamente, según proceda, en los procesos que contribuyan a la adopción de decisiones, la planificación y la aplicación de políticas y programas que fomenten el desarrollo sostenible a todos los niveles.

Reconocemos el papel de la sociedad civil y la importancia de posibilitar que todos los miembros de la sociedad civil participen activamente en el desarrollo sostenible. Reconocemos también que la mejora de la participación de la sociedad civil está supeditada, entre otras cosas, a la ampliación del acceso a la información y a la creación de capacidad de la sociedad civil $\mathrm{y}$ de un entorno propicio. Reconocemos además que la tecnología de la
} 
perspectiva analisar-se-á por conseguinte, a implementação do Princípio 10 nos países da América Latina, a dimensão da relevância que se imprime ao acesso à informação ambiental em território latino-americano, assim como as possíveis influências externas advindas que podem obstar ou prejudicar a concretização do Princípio 10 na América Latina.

\section{O ACESSO À INFORMAÇÃO AMBIENTAL NA AMÉRICA LATINA: A DECLARAÇÃO SOBRE O PRINCÍPIO 10 NA AMÉRICA LATINA E NO CARIBE}

No ano de 2012, realiza-se nova Conferência das Nações Unidas que visa sedimentar as questões introduzidas pela Declaração do Rio de 1992, primando-se nessa oportunidade pela erradicação da fome e pela proposição de alternativas para o desenvolvimento sustentável. Oportunamente, países signatários latino-americanos e caribenhos resolvem engajar esforços para a consagração do Princípio 10, através de ações que visam a criação de um instrumento regional comum, com vistas a garantir o acesso à informação ambiental nos termos exarados pelo Princípio 10.

Este desafio conjunto é firmado por meio da Declaração sobre o Princípio 10 na América Latina e no Caribe, a qual manifesta o compromisso dos países idealizadores (Chile, Costa Rica, Equador, Jamaica, México, Panamá, Paraguai, Peru, República Dominicana e Uruguai) de implementarem um plano de ação cuja vigência seria entre os anos de 2012 e 2014, com o apoio da Comissão Econômica para a América Latina e o Caribe - CEPAL, visando efetuar as ações necessárias para a implantação de um instrumento regional garantidor da aplicabilidade do Princípio 10 nos Estados contratantes.

Atualmente a referida Declaração possui 20 países signatários, dentre eles o Brasil.

Partindo de tais elucidações, pretende-se então analisar as conquistas e os percalços encontrados no caminho para a concretização do plano proposto pela América Latina e Caribe na Conferência Rio + 20 no ano de 2012.

\subsection{A DECLARAÇÃO SOBRE O PRINCÍPIO 10 NA AMÉRICA LATINA E NO CARIBE:} A IMPLANTAÇÃO DE MECANISMOS ESTRUTURADORES PARA O ADVENTO DE UM INTRUMENTO REGIONAL COMUM ASSECURATÓRIO DO DIREITO DE ACESSO À INFORMAÇÃO AMBIENTAL

información y las comunicaciones facilita la circulación de información entre los gobiernos y la población. En este sentido, es indispensable trabajar para mejorar el acceso a la tecnología de la información y las comunicaciones, especialmente las redes y servicios de banda A/RES/66/288 10 ancha, y cerrar la brecha digital, reconociendo la contribución de la cooperación internacional a este respecto (RESOLUÇÃO 66/288, 2012, p. 09 -10). 
A partir da superveniência da Declaração sobre o Princípio 10 na América Latina e no Caribe, o aprofundamento de estudos quanto as ações que deveriam ser consideradas para a elaboração de um instrumento regional comum, inicia a partir da elaboração de um roteiro: hoja de ruta, visando iniciar un proceso destinado a fortalecer el diálogo y la cooperación regional y contar con un instrumento regional en matéria de derechos de acceso a la información, participación y justicia ambientales (2012, p. 02), cujos objetivos principais e princípios passam a ser delineados.

Por conseguinte, em conformidade com o roteiro antes elaborado, houve a confecção de um Plano de Ação (2013) que passou a estabelecer tarefas a serem executadas por grupos de trabalhos distintos, os quais possuíam o objetivo de congregar elementos para a posterior elaboração do instrumento regional para implementação do Princípio 10 no plano prático até o ano de 2014, cuja coordenação ficou a cargo da Comissão Econômica para a América Latina e o Caribe - CEPAL com a promoção de modalidades de participação do público interessado.

Posteriormente, pela ocasião da Tercera Reunión de los Puntos Focales Designados por los Gobiernos de los Países Signatarios de la Declaración sobre la aplicación del Principio 10 de la Declaración de Río sobre el Medio Ambiente y el Desarrollo en América Latina y el Caribe, ocorrida na cidade de Lima no Peru, deu-se origem à Visión de Lima para un Instrumento Regional sobre los Derechos de Acceso en Materia Ambiental (2013), onde sedimentou-se as conclusões provenientes das ações concretizadas até então. No corpo do referido documento foram estabelecidas visões comuns entre os Estados signatários: tais visões dizem respeito a convicções e opiniões uníssonas entre tais estados, contemplando-se ainda no documento em questão, valores e princípios que iriam reger a confecção do instrumento regional para a implementação prática do Princípio 10.

Ainda na mesma oportunidade, houve o estabelecimento de linhas de ações prioritárias $^{6}$, a serem desenvolvidas no ano de 2014, pelo grupo de trabalho sobre fortalecimento de capacidades e cooperação. Tais linhas de ações designavam tarefas contínuas e interligadas a serem efetivas em território latino-americano, havendo por fim a elaboração de pontos conclusivos capazes de demonstrar as necessidades, fragilidades e pontos positivos existentes que embasariam a confecção do instrumento regional comum.

Em novembro de 2014, após a realização de os estudos propostos até então pelo roteiro inicial: hoja de ruta, realiza-se a Cuarta Reunión de los Puntos Focales Designados por los Gobiernos de los Países Signatarios de la Declaración sobre la Aplicación del

\footnotetext{
${ }^{6}$ Disponível em: http://www.cepal.org/dmaah/noticias/noticias/9/54369/Lineas_de_accion_prioritarias_2014_GT1_LIMA.pdf
} 
principio 10 de la Declaración de Río sobre el Medio Ambiente y el Desarrollo en América Latina y el Caribe em Santiago do Chile, oportunidade em que seriam elaborados dois documentos: Contenidos de San José (2014) e Decisión de Santiago (2014).

O primeiro documento, trazendo os resultados advindos de estudos e ações anteriores, com vistas a aplicação cabal de um instrumento regional comum enquanto medida necessária para o efetivo cumprimento do Princípio 10, passa a propor de maneira fundamentada um modelo estruturado do instrumento regional que deveria ser implementado. Já o segundo documento, dando continuidade às disposições apresentadas pelo primeiro, aprova as disposições sugeridas pelos Contenidos de San José a fim de serem consideradas quando da elaboração do instrumento regional, bem como dispõe regras para o início das negociações efetivas visando a criação do instrumento regional, disponibilizando canais de participação pela sociedade civil, que poderia então opinar e sugerir questões a serem insertas no instrumento regional.

A partir daí, diversas foram as contribuições advindas da sociedade civil, representadas por instituições de ensino superior, associações, fundações, ONG's e cidadãos. De 05 à 07 de maio de 2015, realiza-se então a Primera Reunión del Comité de Negociación del Acuerdo Regional sobre el Acceso a la Información, la Participación Pública y el Acceso a la Justicia en Asuntos Ambientales en América Latina y el Caribe, apresentando-se nessa oportunidade o Documento Preliminar del Instrumento Regional sobre el Acceso a la Información, la Participación Pública y el Acceso a la Justicia en Asuntos Ambientales en América Latina y el Caribe (2015).

Apesar dos avanços obtidos em dois anos de estudos, com a edição do documento preliminar consistente no instrumento regional a ser implementado - o qual configurar-se-á como um acordo regional - há inúmeras questões pertinentes ao cenário socioeconômico da América Latina e das demais regiões do globo economicamente desenvolvidas, as quais vislumbram o território latino-americano como objeto para a geração de capital, influenciadoras das variáveis consistentes em facilitar ou dificultar a adesão plena dos Estados signatários ao acordo regional, no que diz respeito a implementação efetiva dos ditames insertos no instrumento regional pertinente a aplicação do Princípio 10. Nesse prisma, desenvolver-se-á o presente assunto a seguir. 


\title{
2.2 PERCALÇOS NA PROMOÇÃO DO ACESSO À INFORMAÇÃO AMBIENTAL E À IMPLEMENTAÇÃO FÁTICA DO ACORDO REGIONAL: A INFLUÊNCIA ECONÔMICA MUNDIAL EM FACE DA AMÉRICA LATINA
}

Ao tratar-se da informação ambiental no âmbito da América Latina, torna-se irremediável referir a influência dos aspectos econômicos - e mais especificamente dos ditames capitalistas que circundam o aporte socioeconômico dos países desenvolvidos quanto as características que perfazem a transmissão da informação: pois nem sempre poderá corresponder a veracidade da situação real a que concerne, assim como nem sempre a informação é repassada em sua integralidade, principalmente quando refere-se a informação de natureza ambiental, o que se observará adiante.

Em contrapartida, tão somente em virtude da disseminação da informação ambiental é que ações globais começaram a ser implementadas para conter a crise ambiental, as quais por sua vez seriam também pressuposto de objetivos eminentemente econômicos. Acerca do assunto, Fernando Estenssoro Saavedra assevera:

\begin{abstract}
A partir deste momento, então, como em qualquer processo histórico, podemos distinguir diferentes subfases, dentro deste primeiro grande período de debate sobre a política ambiental que traçamos entre 1945 e 1992. A primeira subfase são os antecedentes imediatos que permitiram frisar o imaginário político primeiro mundista para chegar a propor a realização da Conferência Mundial sobre o Meio Ambiente Humano de Estocolmo de1972, e por isso devem ser analisados antes do processo da conferência em si. Entre estes devemos considerar: os avanços na disseminação da ecologia como uma disciplina científica, os primeiros escritos de grande divulgação por parte de membros da comunidade científica, que assumem uma atitude militante diante de problemas relacionados com a crise ambiental; o impacto da mídia sobre os primeiros acidentes que geram grandes desastres ecológicos,o surgimento de um movimento social ecologista e/ou ambientalista contemporâneo; o interesse político, estratégico e econômico dos EUA pela questão da crise ambiental e as ações da Organização das Nações Unidas - ONU - anteriores à realização da Conferência de Estocolmo de 1972 (2014, p. 61).
\end{abstract}

Ainda que a divulgação e por consequência o acesso à informação ambiental no caso citado, tenha sido impulsionado por interesses político, estratégico e econômico, como refere o autor ${ }^{7}$, os mesmos interesses podem ser utilizados para finalidade inversa: a não divulgação

\footnotetext{
7 Buscando-se explicitar da melhor forma, as questões favorecedoras da difusão da informação ambiental enquanto medida com cunho econômico favorecida pelos países desenvolvidos, veja-se a seguinte explanação do referido autor, Fernando Estenssoro Saavedra: Desde uma perspectiva histórica, o debate ambiental na política mundial surgiu após o fim da Segunda Guerra Mundial, como uma temática de interesse geopolítico e estratégico para as elites intelectuais, políticas e econômicas norte-americanas. Interesse esse que rapidamente foi compartilhado por seus aliados europeus ocidentais. É um debate que, originado em torno da ideia de crise ambiental global, será uma expressão dos diferentes argumentos e alternativas possíveis de avaliar, por parte dos Estados Unidos e seus aliados, para evitar o avanço do comunismo em âmbito mundial e contê-lo dentro das fronteiras e áreas de influência soviética que foi negociada em Yalta e Potsdam.

Sobre isso, a temática da crise ambiental, em primeiro lugar surgiu em meio a um debate maior que significava a política de contenção do comunismo na nascente guerra fria e, em segundo lugar, foi um argumento alternativo ou um contraargumento à crença dominante das elites políticas de que o avanço do comunismo no Terceiro
} 
da informação ambiental, tornando-a inacessível. É sob esse paradigma que a análise da influência dos países desenvolvidos deve ser observada, enquanto averigua-se a eficácia prática do Acordo Regional sobre o Acesso à Informação, à Participação Pública e o Acesso à Justiça nos Assuntos Ambientais na América Latina e no Caribe.

Obviamente que, as hipóteses de inacessibilidade à informação ambiental ou então a manipulação da informação ambiental decorre da modificação das perspectivas do discurso implementado em determinado espaço-tempo. Veja-se que as ideias incorporadas na sociedade através da manipulação da informação ambiental, direcionam as práticas e os pensamentos que serão difundidos. Assim, partindo-se de um paradigma que gera a informação ambiental a partir de discursos hegemônicos pré-determinados, há a inacessibilidade da informação ambiental: seja pela inexistência da informação propriamente dita, seja pela imposição de um discurso que distancia-se da realidade ambiental vivenciada, praticando-se assim a insustentabilidade informacional.

Nesse sentido Enrique Leff demonstra com perfeição, como a modificação do discurso hegemônico pode ser preponderante para a inacessibilidade ou manipulação da informação ambiental, aliado à impulsão permanente ao consumo:

As estratégias de apropriação dos recursos naturais do Terceiro Mundo no marco da globalização econômica se reconfiguraram nas perspectivas da sustentabilidade. Antes a impossibilidade de assimilar as condições de sustentabilidade e os princípios que orientam a construção de uma racionalidade ambiental, a política de desenvolvimento sustentado vai desativando, diluindo e pervertendo as perspectivas abertas pelo conceito crítico do ambiente a um desenvolvimento alternativo. Se nos anos 1970 a crise ambiental tornou necessário que se colocasse um freio antes que o colapso ecológico fosse alcançado, a partir dos anos 1980 o discurso neoliberal anunciou a desaparição da contradição entre ambiente e crescimento. Os mecanismos de mercado são postulados como o meio mais correto de assimilação das condições ecológicas e dos valores culturais ao processo de crescimento econômico. Na perspectiva neoliberal, desaparecem as causas econômicas dos problemas ecológicos. A crise ambiental não é mais um efeito da acumulação de capital, mas resultado do fato de não haver outorgado direitos de propriedade (privada) e atribuído valores (de mercado) aos bens comuns. Uma vez estabelecido o anterior - afirma o discurso do desenvolvimento sustentado -, as leis clarividentes do mercado se encarregariam de ajustar os desequilíbrios ecológicos e as diferenças sociais, a equidade e a sustentabilidade (2006, p. 139).

A problemática assume maiores contornos quando percebe-se que a hegemonia de determinado discurso - e nesse caso os discursos econômicos e de mercado - pode não só manipular o acesso à informação ambiental nos moldes antes referidos, como também tem o condão de direcionar as ações governamentais. Nesse diapasão, atos governamentais concretizam-se ou deixam de concretizar-se em virtude de discursos aliados à possibilidade de

Mundo em geral e na América Latina em particular, podia ser freado mediante a elevação do nível de vida de seu povo faminto, apoiando-os para alcançar o status de países desenvolvidos mediante um processo de modernização e industrialização crescente (2014, p. 211). 
crescimento ou desenvolvimento econômico impulsionado por transnacionais capazes de direcionar a economia de países subdesenvolvidos.

Sob esse aspecto, passa-se a averiguar de modo específico os embates que envolvem o Projeto de Lei ${ }^{\circ}$. 4148/2008 que tramita atualmente no Congresso Nacional brasileiro e as diretrizes que a Declaração sobre o Princípio 10 na América Latina e no Caribe e, por conseguinte, o Documento Preliminar acerca do Acordo Regional sobre o Acesso à Informação, à Participação Pública e o Acesso à Justiça nos Assuntos Ambientais na América Latina e no Caribe instituem, vislumbrando-se claramente no presente caso as contradições postas quanto ao acesso à informação ambiental no Brasil, em virtude da hegemonia de discursos com finalidades puramente econômicas.

\section{AS CONTRAPOSIÇÕES EXISTENTES ENTRE O PROCESSO DE IMPLANTAÇÃO DO PRINCIPIO 10 NA AMÉRICA LATINA E O PROJETO DE LEI $n^{0}$. 4148/2008 NO BRASIL: DISCREPÂNCIAS EM PROL DO MERCADO}

A aprovação do Projeto de Lei $n^{\circ}$. 41482008 na Câmara dos Deputados Federais provocou enorme repercussão social, atingindo setores como fundações, associações e ONG's ambientais, comunidade acadêmica e sociedade civil. Não podendo ser diferente, o texto do referido projeto de lei coloca em voga os fundamentos que embasam o acesso à informação ambiental e por consequência, a aplicação dos ditames inseridos no Princípio 10, bem como a ratificação do Brasil à Declaração sobre o Princípio 10 na América Latina e no Caribe.

É cediço que, as proposições iniciais que embasaram o projeto de lei possuíam e ainda possuem conteúdo com o objetivo de privilegiar os aspectos lucrativos ligados a transgenia, pretendendo-se retirar a simbologia com caráter informacional que alerta para a existência de organismos geneticamente modificados em produtos a serem adquiridos para consumo. As modificações que se pretende implantar nas rotulagens de alimentos transgênicos possui claramente o objetivo de fomentar o consumo e a produção de tais alimentos através da omissão dos caracteres negativos impregnados na transgenia. Para melhor compreensão acerca do assunto, passa-se a analisar minuciosamente os pressupostos embasadores e a persecução do Projeto de Lei nº. 4148/2008. 


\subsection{A TRAMITAÇÃO DO PROJETO DE LEI Nº . 4148/2008 NO CONGRESSO NACIONAL E SEUS PRESSUPOSTOS EMBASADORES}

O Projeto de Lei ${ }^{\circ}$. 4148/2008, proposto pelo Deputado Luis Carlos Heinze em 16 de outubro de 2008, propõe a alteração da Lei $\mathrm{n}^{\circ}$. $11.105 / 2005$, mais especificamente no texto do seu artigo 40, acrescendo os parágrafos primeiro, segundo e terceiro do referido artigo.

Ao acessar o sítio do Congresso Nacional, observa-se que no campo referente à explicação da ementa relativa ao projeto em questão está descrito: Estabelece que os rótulos dos alimentos destinados ao consumo humano informem ao consumidor a natureza transgênica do alimento, embora se tenha conhecimento da existência prévia de legislação brasileira correspondente ao assunto: a própria Lei n. 11.105/2005, regulamentada pelo Decreto $n^{\circ}$. 4680/2003, que há muito disciplinam e obrigam que a informação quanto à presença de organismos geneticamente modificados esteja presente na rotulagem de alimentos. Vislumbra-se então que, a intenção primordial que permeia a proposição do Projeto de Lei ño 41482008 e o seu próprio conteúdo - o que será demonstrado a seguir - , não estão de pleno acordo com a informação que o campo de explicação da ementa transmite publicamente.

Dessa forma, em meio à análise minuciosa do projeto de lei submetido, constata-se que o mesmo não trás qualquer benesse que tenha o condão de privilegiar o acesso à informação ambiental, contrariamente, o Projeto de Lei $n^{\circ}$. 4148/2008 trás regressões e restrições ao acesso à informação ambiental. Tal afirmação sustenta-se através da simples averiguação de determinadas disposições legais em comparação com o projeto de lei em tramitação.

Assim, observe-se o texto legal do artigo 40 da Lei $n^{\circ}$. 11.105/05, sem a alteração prevista, e sua regulamentação através do Decreto nº. 4680/2003: Art. 40. Os alimentos e ingredientes alimentares destinados ao consumo humano ou animal que contenham ou sejam produzidos a partir de OGM ou derivados deverão conter informação nesse sentido em seus rótulos, conforme regulamento (grifo nosso). Já o Decreto ${ }^{\circ}$. 4680/2003, assim prevê:

\footnotetext{
Art. $2^{\circ}-\mathrm{Na}$ comercialização de alimentos e ingredientes alimentares destinados ao consumo humano ou animal que contenham ou sejam produzidos a partir de organismos geneticamente modificados, com presença acima do limite de um por cento do produto, o consumidor deverá ser informado da natureza transgênica desse produto.

$\S 1^{\circ}-$ Tanto nos produtos embalados como nos vendidos a granel ou in natura, o rótulo da embalagem ou do recipiente em que estão contidos deverá constar, em destaque, no painel principal e em conjunto com o símbolo a ser definido mediante ato do Ministério da Justiça, uma das seguintes expressões, dependendo do caso: "(nome do produto) transgênico", "contém (nome do ingrediente ou ingredientes) transgênico(s)" ou "produto produzido a partir de (nome do produto) transgênico".
} 
$\S 2^{\circ}-O$ consumidor deverá ser informado sobre a espécie doadora do gene no local reservado para a identificação dos ingredientes.

$\S 3^{\circ}-\mathrm{A}$ informação determinada no $\S 1^{\circ}$ deste artigo também deverá constar do documento fiscal, de modo que essa informação acompanhe o produto ou ingrediente em todas as etapas da cadeia produtiva.

$\S 4^{\circ} \mathrm{O}$ percentual referido no caput poderá ser reduzido por decisão da Comissão Técnica Nacional de Biossegurança - CTNBio.

Art. $3^{-}$Os alimentos $\mathrm{e}$ ingredientes produzidos a partir de animais alimentados com ração contendo ingredientes transgênicos deverão trazer no painel principal, em tamanho e destaque previstos no art. $2^{\circ}$, a seguinte expressão:

"(nome do animal) alimentado com ração contendo ingrediente transgênico" ou "(nome do ingrediente) produzido a partir de animal alimentado com ração contendo ingrediente transgênico" (...) (grifo nosso).

Por sua vez, a simbologia citada no parágrafo $1^{\circ}$. do artigo $2^{\circ}$. do Decreto 46802003, foi estabelecida pela Portaria $n^{\circ}$. 2658/2003 emitida pelo Ministério da Justiça, que assim dispõe:

O MINISTRO DE ESTADO DA JUSTIÇA, no uso de suas atribuições e considerando o disposto no parágrafo $1^{\circ}$, do artigo $2^{\circ}$, do Decreto 4.680, de 24 de abril de 2003, resolve:

Art. $1^{\circ}$ - Definir o símbolo de que trata o art. $2^{\circ}, \S 1^{\circ}$, do Decreto 4.680, de 24 de abril de 2003 , na forma do anexo à presente portaria.

Art. $2^{\circ}$ - Esta portaria entra em vigor no prazo de 60 dias contados da data de sua publicação.

MÁRCIO THOMAZ BASTOS

ANEXO

REGULAMENTO PARA O EMPREGO DO SÍMBOLO TRANSGÊNICO

1. ÂMBITO DE APLICAÇÃO E OBJETIVOS: O presente regulamento se aplica de maneira complementar ao disposto no Regulamento Técnico para Rotulagem de Alimentos Embalados aprovado pela resolução da Diretoria Colegiada da Agência Nacional de Vigilância Sanitária de $\mathrm{n}^{\circ} 259$, de 20 de setembro de 2002, ou norma que venha a substituir, e tem o objetivo de definir a forma e as dimensões mínimas do símbolo que comporá a rotulagem tanto dos alimentos e ingredientes alimentares destinados ao consumo humano ou animal embalados como nos vendidos a granel ou in natura, que contenham ou sejam produzidos a partir de organismos geneticamente modificados, na forma do Decreto $\mathrm{n}^{\circ} 4.680$, de 24 de abril de $2003(\ldots)$.

As razões que embasam o Projeto de Lei $n^{\circ} .41482008^{8}$, em comparação com a legislação antes referida, possuem dois objetivos claros: a retirada da simbologia que indica a

\footnotetext{
${ }^{8}$ Tendo em vista que se considera indispensável a aposição de tais razões no presente trabalho, busca-se então elencar tão somente os motivos que ensejam as três modificações citadas no texto, as quais pregam o retrocesso à informação ambiental:

III - Formato da informação: Três outros itens que dizem respeito à forma de prestar a informação nos alimentos transgênicos, também merecem disciplina mais adequada e que resultaram nas redações dos $\S \S 1^{\circ}, 2^{\circ}$ e $3^{\circ}$, a saber: 1) Indicação da espécie doadora do gene; Entendemos que a indicação da espécie doadora do gene não traz benefício ao consumidor, uma vez que de difícil compreensão (nomes científicos), contrariando, desse modo, o disposto nos artigos $6^{\circ}$ e 31 do Código de Defesa do Consumidor, que exige o fornecimento ao consumidor de informações claras e que não o levem a erro ou falso entendimento. Por essa razão, a informação contemplada no $\S 2^{\circ}$, art. $2^{\circ}$, do Decreto $n^{\circ} 4.680 / 03$ não se refletiu na presente proposta. 2) Aposição de símbolo no rótulo; e, Quanto a inserção de símbolo junto à informação de transgênia, conforme disciplinado no Decreto $\mathrm{n}^{\circ} 4.680 / 03$ e na Portaria $\mathrm{n}{ }^{\circ} 2.658 / 03$, julgamos inapropriada a sua utilização para indicação da presença de DNA ou proteína resultante da modificação genética, pelos motivos que seguem. As normas de rotulagem de alimentos estabelecidas no Mercosul e no Codex Alimentarius, não apresentam dispositivos
} 
existência de transgênicos e da informação sobre a espécie doadora do gene existente no produto a ser consumido, e a retirada das informações de alimentos e ingredientes produzidos a partir de animais alimentados com ração contendo ingredientes transgênicos da rotulagem de tais produtos. Aprovado na Câmara dos Deputados Federais, o Projeto de Lei nº. 4148/2008 aguarda apreciação do Senado Federal. O Senado por sua vez, disponibiliza em seu sítio uma enquete sobre o projeto de lei, de forma que os cidadãos podem manifesta-se a favor ou contra. Até a tarde do dia 02 de junho de 2015, haviam 11.277 votos contra o projeto de lei e 703 votos a favor.

Sem sombra de dúvidas tais alterações legais no Brasil pregam a desinformação, o retrocesso normativo quanto ao acesso à informação ambiental, contrariando veementemente o processo pertinente a confecção do Instrumento Regional sobre o Acesso à Informação, à Participação Pública e o Acesso à Justiça em Assuntos Ambientais na América Latina e no Caribe, enquanto país signatário, contrapondo-se totalmente aos ditames do Princípio 10. Por fim, resta averiguar então a relação dos aspectos econômicos, de mercado, e dos investimentos transnacionais no Brasil com o Projeto de Lei $n^{\circ} .4148 / 2008$ e a clara afronta legal aos fundamentos do Princípio 10.

\subsection{A AFRONTA LEGAL AO PRINCÍPIO 10 PELO PROJETO DE LEI Nº. 4148/2008: SUA RELAÇÃO COM O MERCADO MUNDIAL E O INVESTIMENTO EM SOLO BRASILEIRO POR TRANSNACIONAIS}

De acordo com informações provenientes de sítio governamental e de monopólio da comunicação no país, o Brasil é vice líder mundial na produção de transgênicos, condição que

\footnotetext{
específicos de rotulagem dos produtos produzidos a partir de organismos geneticamente modificados e seus derivados. As exigências do Decreto $\mathrm{n}^{\circ} 4.680 / 03$ e da Portaria $\mathrm{n}^{\circ} 2.658 / 03$ provocam sérios problemas nas relações comerciais internacionais, uma vez que o Brasil é o único país do mundo a adotar um símbolo de alerta em produtos aprovados para consumo humano. As normas brasileiras não se baseiam em nenhum precedente internacional ao instituir o símbolo, que de resto, somente agrega valor negativo ao produto. Cabe ainda ressaltar que a apresentação gráfica (formato e cores) do símbolo disciplinado na Portaria $\mathrm{n}^{\circ} 2.658$, de 22 de dezembro de

2003, é utilizada em placas de advertência, atenção e existência de risco, afixadas em locais de perigo, radiação, eletricidade, explosão, entre outros. Assim, o símbolo em questão vincula o alimento, que contenha DNA ou proteína obtida através de organismo geneticamente modificado, a circunstâncias de perigo, nocividade, cuidado, alerta, e outras mais para as quais a apresentação gráfica é usualmente destinada. Esta correspondência entre o símbolo (triângulo amarelo e preto) e suposto "risco" de consumo afeta a imagem de qualidade dos produtos, bem como, a exigência da cor amarela gera altos custos com embalagens, haja vista que, muitas vezes, esta cor não compõe a rotulagem usual dos produtos.3) Rotulagem de alimentos e ingredientes produzidos a partir de animais alimentados com ração com ingredientes transgênicos. Certo é também, que inexiste no mercado internacional regras de rotulagem para produtos produzidos a partir de animais alimentados com OGM, bem como, em hipóteses muito restritas, se exige a rotulagem quando ausente a proteína ou DNA resultantes de técnica de engenharia genética, sendo provável que os importadores entendam tais exigências como a criação de barreiras não tarifárias, e pior, não justificadas tecnicamente, passível, ainda, de gerar, em contraposição, restrições em exportações. A exclusão de previsão de rotulagem de alimentos destinados a animais também carecem de justificativa técnica nos moldes acima(2008, p. 05-07).
} 
vem se mantendo nos últimos anos, com aumento expressivo e progressivo na produção anual, estando atrás somente dos Estados Unidos.

Por conseguinte, a economia do país e o seu desenvolvimento estão intimamente atrelados a implantação da transgenia no Brasil, a qual impulsiona e rentabiliza a produção de monoculturas através de modificações genéticas resistentes à pragas, herbicidas e ações do tempo, favorecendo o índice de produtividade e lucratividade das lavouras ${ }^{9}$.

Em contraposição, diversas são as pesquisas que comprovam os malefícios do consumo de transgênicos para a saúde humana, bem como a desnecessidade da produção de alimentos com organismos geneticamente modificados para a garantia da segurança alimentar em âmbito mundial e os malefícios provenientes das grandes produções de monoculturas transgênicas à biodiversidade como um todo.

Diante de tais argumentos, atualmente a justificação para o cultivo desenfreado de transgênicos passa a ser tão somente a relevância de tais produções para a expansão da economia mundial.

Sob esse aspecto, Carlos Walter Porto - Gonçalves expõe diversos argumentos que sustentam tal alegação a fim de comprovar a preponderância dos aspectos econômicos representados por investimentos transnacionais e hegemonia das empresas detentoras do conhecimento científico para o desenvolvimento e produção de herbicidas e sementes geneticamente modificadas, que provocam dependência na produção das monoculturas.

No Brasil, o desenvolvimento do novo modelo agrário/agrícola também mostra o
mesmo sentido ao apontar para um modelo onde o monocultivo acentua a
dependência do agricultor diante do complexo industrial-financeiro altamente
oligopolizado e, com isso, aumenta a insegurança alimentar, tanto dos agricultores e
suas famílias como do país como um todo. A produção de soja no Rio Grande do
Sul, até os anos de 1960, estava associada à produção de trigo, de milho e a
pastagens para gado bovino, além da criação de porcos e todos os seus derivados
(banhas, linguiças, etc.). Desde os anos de 1970 esse sistema de uso da terra, e toda
a cultura a ele associado, vem sendo substituído por um sistema que tende para o
monocultivo sobretudo da soja, com toas as implicações que daí deriva.
Consideremos que no antigo sistema de rotação de culturas, a soja, na verdade,
subsidiava o solo com azoto (nitrogênio) e, além disso, a criação de animais garantia
não só decanso (pousio) da terra, como também parte do adubo (esterco) e, com

\footnotetext{
${ }^{9}$ A fim de embasar, tal alegação veja-se a exposição de Carlos Walter Porto-Gonçalves à respeito: Ainda que o cultivo de soja venha se expandindo na Argentina desde os anos de 1980 "sua associação com o plantio direto e a utilização de sementes geneticamente modificadas (GM) (sic) Roundup Ready (RR) - resistentes ao herbicida glifosato - marcou um ponto de inflexão, a partir do qual se produziu um crescimento vertiginoso que colocou a soja como o cultivo mais semeado em nível nacional, seguido pelo trigo. A simplificação do manejo das pragas através de um só herbicida foi a ponta de lança para o exitoso ingresso desta variedade desenvolvida pela firma estadunidense Monsanto, que possui as patentes de seus direitos de propriedade sobre as sementes RR e sua descendência" (Bacwell e Stefanni). "Na província de Catamarca (Argentina) estão sendo produzidas duas colheitas de soja por ano. Imediatamente atrás das colhetadeiras vamos semeando a soja para a segunda produção", explica o chefe de produção da empresa Ingeco AS, Felipe Torres Posse, que afirma que "a equação econômica é muito boa sob este esquema, razão pela qual as duas colheitas anuais de soja poderão se estender a toda a região do Noroeste sob irrigação" (2012,p.235).
} 


\begin{abstract}
isso, proporcionava as condições ideais para o cultivo exigente do trigo. O trigo se constituía no centro desse sistema de uso da terra, que visava garantir o abastecimento nacional do pão nosso de cada dia e, assim, a segurança alimentar. Dessa forma, a segurança alimentar que esse sistema representava matinha fortes relações com a própria estrutura agrária a Zona Colonial gaúcha que, desde o início, visava o abastecimento das tropas que guardavam a fronteira na Campanha Gaúcha. Vê-se que esse sistema de uso da terra estava associado à ideia de um projeto nacional. Não estranhemos pois, que a insegurança alimentar mantenha fortes relações com um sistema agrárioagrícola que visa a mercantilização generalizada como o que vem caracterizando o período neoliberal da globalização (2012, p. 222 223).
\end{abstract}

Tais razões são consistentes o bastante para sedimentar a alegação de grande influência das questões econômicas no Projeto de Lei nº. 4148/2008. Obviamente, pregar a desinformação ambiental através da retirada da simbologia que indica a presença de organismos geneticamente modificados nos alimentos, faz com que qualquer ponto relacionado a possíveis riscos para a saudade humana seja ignorado pelo consumidor, retirando-se ainda a possibilidade de opção pelo consumo de transgênicos ou produtos sem a utilização de transgenia.

Segundo o projeto de lei, o aspecto atinente à informação ambiental seria preservado através da manutenção da palavra transgênico junto aos ingredientes que perfazem o produto. No entanto sabe-se que a aposição de informações a respeito dos ingredientes que perfazem o produto não se localiza em ponto visível o suficiente, que seja capaz de garantir efetivamente que o consumidor tenha consciência de que está adquirindo alimento com conteúdo transgênico. Ademais, havendo disposição legal que fixa a utilização da simbologia em rótulos de alimentos com organismos geneticamente modificados, a sua substituição por lei que preveja o contrário configura-se em um grande retrocesso na seara da informação ambiental.

Assim, é evidente a grande contraposição existente entre os atuais paradigmas que o Brasil vem traçando no que tange a sustentabilidade da informação ambiental com o Projeto de Lei $\mathrm{n}^{\mathrm{o}}$. 41482008, e aqueles paradigmas através dos quais se filiou sendo signatário da Declaração sobre o Princípio 10 na América Latina e no Caribe.

O impacto informacional na era contemporânea aliado aos resultados mercadológicos que é capaz de produzir, além da relevância da transgenia enquanto condição indispensável para o desenvolvimento de monoculturas em larga escala e meio de fomento da economia brasileira, possui o condão de desvirtuar totalmente as finalidades intrínsecas na ratificação pelo Brasil junto à declaração antes referida.

Pelos argumentos aqui referidos, percebe-se que é clara a influência derivada do capital no Projeto de Lei ${ }^{\circ}$. 4148/2008, pressupondo a mitigação da informação ambiental 
nesse caso. Ainda que a transgenia seja uma das grandes responsáveis pelo sucesso do agronegócio brasileiro, pode suscitar-se que a influência econômica direta sobre a edição de atos normativos e sobre decisões de qualquer âmbito acerca da informação ambiental, acarreta o desmoronamento de ideais que embasaram diversas conquistas nesse aspecto, a fim de evitar e deslegitimar ações como a presente: que contrariam veementemente as diretrizes internacionais acerca do assunto, e desconsideram sobremaneira a relevância global atribuída à informação ambiental através do Princípio 10.

\section{CONCLUSÃO}

As perspectivas exitosas que permeiam a era informacional, geram a certeza dos benefícios advindos da sustentabilidade da informação nos mais diversos campos de atuação humana, a fim de difundir ideias e diretrizes que permitam a existência de esforços mútuos em diferentes espaços geográficos, para a efetivação de objetivos que assumem caráter global.

Sem dúvida alguma, tal fato assume contornos extremamente positivos quando se trata de informações ambientais sustentáveis, sendo louvável a iniciativa dos países latinoamericanos e caribenhos idealizadores da proposta de confecção de um instrumento regional para consagração do Princípio 10 na América Latina e Caribe, o qual se encontra em vias de concretização na forma de um acordo regional, que embora não possua caráter vinculativo representa um grande avanço no que tange ao tratamento da questão informacional ambiental no continente, bem como a garantia da informação sustentável.

Todavia, independentemente da inexistência de vinculação as disposições do referido instrumento, o que não pode ocorrer é a desconsideração total dos fundamentos embasadores do acordo regional, por país signatário da Declaração sobre o Princípio 10 na América Latina e no Caribe.

Nesse ponto, o fato é que o posicionamento adotado pelo Poder Legislativo brasileiro - Câmara dos Deputados - que culminou na aprovação do Projeto de Lei nº 41482008 , demonstra o atual descompasso quanto a lógica das ações que dão origem ao Documento Preliminar acerca do Acordo Regional sobre o Acesso à Informação, à Participação Pública e o Acesso à Justiça nos Assuntos Ambientais na América Latina e no Caribe.

Obviamente, as influências econômicas e mercadológicas de caráter transnacional concernentes a necessidade de fomento do agronegócio brasileiro e da alta lucratividade proporcionada pela produção de organismos geneticamente modificados - condição que 
impulsiona veementemente a economia do país -, são decisivas para a não disseminação e insustentabilidade de informações acerca de alimentos com conteúdo transgênico ou ainda para a redução dos caracteres informativos: dualidade de pretensões insertas no Projeto de Lei $n^{0} .4148 / 2008$.

Dessa forma, ainda que o projeto de lei ainda esteja em tramitação, tem-se que tão somente a manifestação volitiva dos congressistas da Câmara dos Deputados representada pelos discursos favoráveis, pela própria fundamentação do projeto de lei e pela aprovação do mesmo, possui a capacidade de demandar grande preocupação com o tratamento que o Brasil vem concedendo à questões relacionadas com a informação ambiental, assim como com o descompasso entre as posições defendidas de modo expressivo no Poder Legislativo brasileiro e os compromissos assumidos internacionalmente.

Em meio a tais constatações, pretendendo-se sanar a indagação que induziu a pesquisa que aqui se desenvolve, tem-se que os fundamentos que levaram o Projeto de Lei $\mathrm{n}^{\circ}$. 4148/2008 à apreciação do Congresso Nacional e sua consequente aprovação na Câmara dos Deputados consistem claramente em contraposição não só aos compromissos assumidos pelo Brasil através da Declaração sobre o Princípio 10 na América Latina e no Caribe, mas todo e qualquer compromisso assumido que seja atinente a promoção da informação ambiental e à sustentabilidade da informação, sendo contrário inclusive à toda e qualquer diretriz internacional acerca do direito à informação ambiental que esteja alinhada com a dimensão global do Princípio 10 enquanto propulsor da imprescindibilidade da informação ambiental, de forma que o referido projeto de lei poderá consistir em grande retrocesso normativo, caso ocorra sua aprovação no Senado Federal e sanção pela Presidência da República.

No entanto, cabe salientar que nesse caminho há flores: de acordo com resultado parcial da enquete que está sendo realizada pelo Senado Federal a fim de que os cidadãos possam manifestar-se quanto a aprovação ou não do Projeto de Lei $n^{\circ}$. 4148/2008, a predominância da opinião pública quanto a desaprovação do mesmo é expressiva. Assim, a popularização da questão assume contornos positivos, possuindo a capacidade de ensejar a reestruturação do posicionamento brasileiro internamente, além de possibilitar que a atuação do Poder Público venha a apresentar concordância com o posicionamento assumido internacionalmente e garantir de modo efetivo a sustentabilidade informação ambiental enquanto pressuposto para a concretização de direitos humanos internacionais relacionados com a sociobiodiversidade e a vida em âmbito global. 


\section{REFERÊNCIAS BIBLIOGRÁFICAS}

BRAGA, Fernando Urioste. Derecho de la información. Montevideo: B de F Ltda, 2008.

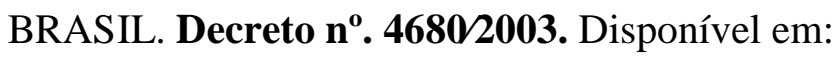

<http://www.planalto.gov.br/ccivil_03/decreto/2003/d4680.htm> - Acesso em 07 de junho de 2015.

BRASIL. Lei $\mathbf{n}^{\mathbf{*}}$ 11.105/2005. Disponível em:

<http://www.planalto.gov.br/ccivil_03/_ato2004-2006/2005/lei/111105.htm> - Acesso em: 07 de junho de 2015.

BRASIL. Portaria no . 2658/2003. Disponível em:

<http://portal.anvisa.gov.br/wps/wcm/connect/1e3d43804ac0319e9644bfa337abae9d/Portaria _2685_de_22_de_dezembro_de_2003.pdf?MOD=AJPERES > - Acesso em: 07 de junho de 2015.

BRASIL. Projeto de Lei $\mathbf{n}^{\mathbf{0}}$. 4148/2008. Disponível em:

<http://www.camara.gov.br/proposicoesWeb/prop_mostrarintegra;jsessionid=BC8A7E9929B 7DA89BD0129213AE57597.proposicoesWeb1? codteor=605180\&filename $=P L+4148 / 2008>$ - Acesso em: 07 de junho de 2015.

BRASIL. Senado Federal. Disponível em: <http://www12.senado.gov.br/ecidadania/visualizacaotexto?id=164869> - Acesso em $02 \mathrm{de}$ junho de 2015.

CANCLINI, Nestor Garcia. Consumidores e cidadãos - conflitos multiculturais da globalização. Rio de Janeiro: UFRJ, 1999.

CASTELLS, Manuel; CARDOSO, Gustavo (Orgs.). A Sociedade em Rede: do conhecimento à ação política. Conferência. Belém (Por) : Imprensa Nacional, 2005.

COMISSÃO ECONÔMICA PARA A AMÉRICA LATINA E O CARIBE - CEPAL. Decisión de Santiago. Disponível em:

<http://repositorio.cepal.org/bitstream/handle/11362/37213/S1420708_es.pdf?sequence=1> Acesso em 07 de junho de 2015.

COMISSÃO ECONÔMICA PARA A AMÉRICA LATINA E O CARIBE - CEPAL

Documento Preliminar del Instrumento Regional sobre el Acceso a la Información, la Participación Pública y el Acceso a la Justicia en Asuntos Ambientales en América Latina y el Caribe. Disponível em:

<http://www.cepal.org/dmaah/noticias/noticias/5/54735/Documento_preliminar_P10_CEPAL _Mayo_2015.pdf > - Acesso em 07 de junho de 2015.

COMISSÃO ECONÔMICA PARA A AMÉRICA LATINA E O CARIBE - CEPAL. Hoja de ruta del proceso de creación de un instrumento sobre la aplicación del Principio 10 en América Latina y el Caribe. Disponível em:

$<$ http://www.cepal.org/dmaah/noticias/noticias/9/54369/2012-854-Rio_20_Hoja_de_ruta_.pdf $>$ - Acesso em 06 de junho de 2015. 
COMISSÃO ECONÔMICA PARA A AMÉRICA LATINA E O CARIBE - CEPAL. Plan de acción hasta 2014 para la implementación de la Declaración sobre la aplicación del Principio 10 de la Declaración de Río sobre el Medio Ambiente y el Desarrollo en América Latina y el Caribe y su hoja de ruta. Disponível em:

$<$ http://www.cepal.org/dmaah/noticias/noticias/9/54369/2013-207-PR10-Plan_de_accion17_abril.pdf $>$ - Acesso em 06 de junho de 2015.

COMISSÃO ECONÔMICA PARA A AMÉRICA LATINA E O CARIBE - CEPAL. Propuesta de naturaleza y contenidos a desarrollar en el instrumento regional para consideración en la Cuarta Reunión de los Puntos Focales designados por los gobiernos de los países signatarios de la Declaración sobre la Aplicación del Principio 10 de la Declaración de Río sobre el Medio Ambiente y el Desarrollo en América Latina y el caribe. Disponível em:

<http://www.cepal.org/dmaah/noticias/noticias/9/54369/Propuesta_de_naturaleza_y_contenid os.pdf $>$ - Acesso em 06 de junho de 2015

COMISSÃO ECONÔMICA PARA A AMÉRICA LATINA E O CARIBE - CEPAL. Visión de Lima para un Instrumento Regional sobre los Derechos de Acceso en Materia Ambiental. Disponível em: <http://www.cepal.org/rio20/noticias/noticias/1/50791/2013913_P10_Vision_LIMA.pdf> - acesso em 06 de junho de 2015.

LEFF, Enrique. Racionalidade ambiental: a reapropriação social da natureza. Trad. Luis Carlos Cabral. Rio de Janeiro: Civilização Brasileira, 2006.

LÉVY, Pierre. A conexão planetária: o mercado, o ciberespaço, a consciência. Trad. Maria Lúcia Homem e Ronaldo Entler. São Paulo: Editora 34, 2001.

LOJKINE, Jean. A revolução informacional. $3^{\text {a }}$ ed. Trad. José Paulo Netto. São Paulo, Cortez, 2002.

MAIA, Ricardo. Brasil só perde para os EUA na produção de transgênicos. Folha Web. Disponível em:< http://www.agrolink.com.br/noticias/brasil-so-perde-para-os-eua-naproducao-de-transgenicos_212390.html> - Acesso em 02 de junho de 2015.

ORGANIZAÇÃO DAS NAÇÕES UNIDAS. Declaração do Rio sobre Meio Ambiente e Desenvolvimento. Disponível em: <http://www.onu.org.br/rio20/img/2012/01/rio92.pdf> Acesso em 05 de junho de 2015.

ORGANIZAÇÃO DAS NAÇÕES UNIDAS. Resolução 66/288. Disponível em:

<http://www.uncsd2012.org/content/documents/778futurewewant_spanish.pdf > - Acesso em 05 de junho de 2015.

PECK, Patrícia. Direito digital. São Paulo: Saraiva, 2002.

PORTO-GONÇALVES, Carlos Walter. A globalização da natureza e a natureza da globalização. 3 ed. Rio de Janeiro: Civilização Brasileira, 2012. 
SAAVEDRA, Fernando Estenssoro. História do debate ambiental na política mundial 1945-1992. Trad. Daniel Rubens Cenci. Ijuí: Unijui, 2014.

TYBUSCH, Jerônimo Siqueira. Ecologia política, sustentabilidade e direito. In Direitos emergentes na sociedade global: Anuário do Programa de Pós-Graduação em Direito da UFSM. Org. TYBUSCH, Jerônimo Siqueira; ARAUJO, Luiz Ernani Bonesso de; SILVA, Rosane Leal da. Ijuí: Unijuí, 2013. 